\title{
Allochthonous subsidies as driving forces for development of plankton in an autotrophic, temperate, and small lake
}

\author{
Małgorzata Adamczuk (D) B Beata Ferencz · Tomasz Mieczan · Jarosław Dawidek
}

Received: 28 June 2018/Revised: 20 June 2019/Accepted: 19 August 2019/Published online: 29 August 2019

(C) The Author(s) 2019

\begin{abstract}
Autotrophic lakes are regarded to function as net autotrophic systems in which mobilization of solar energy by phytoplankton, benthic algae, and macrophytes forms the base of primary production. However, they are also subsided by allochthonous inputs. In this paper, we tested three hypotheses explaining the role of allochthonous subsidies as a driving force of autotrophic, bacterial, and heterotrophic production. The studies for this paper were conducted every fortnight from November 2015 to October 2017 in a small, shallow, temperate, eutrophic lake supplied with waters from four streams and drained by a single outlet. Changes in plankton biomass as well as variations in environmental conditions were estimated on the basis of the samples and measurements collected vertically in the water column
\end{abstract}

Handling editor: Mariana Meerhoff

Electronic supplementary material The online version of this article (https://doi.org/10.1007/s10750-019-04052-9) contains supplementary material, which is available to authorized users.

M. Adamczuk $(\square) \cdot$ B. Ferencz $\cdot$ T. Mieczan

Department of Hydrobiology and Protection of Ecosystems, University of Life Sciences in Lublin,

B. Dobrzańskiego 37, 20-262 Lublin, Poland

e-mail: malgorzata.adamczuk@up.lublin.pl

J. Dawidek

Department of Hydrology, Maria Curie-Skłodowska

University, Kraśnicka 2cd, 20-718 Lublin, Poland (every $0.5 \mathrm{~m}$ depth) in the central part of the lake. Loads of nutrients and organic and inorganic matter were measured in both the inlets and the outlet of the lake, and on the basis of the differences between input and output loading, the amount of allochthonous subsidies in the lake was computed. Allochthonous subsidies affected the autotrophic production directly by supplying assimilable nutrients, and indirectly by providing allochthonous organic matter that supplemented the diet of omnivores and thus hampered their grazing pressure on phytoplankton. Bacterioplankton utilized allochthonous organic matter as well as effectively competed with phytoplankton for allochthonous nutrients. Dominant species of heterotrophic plankton were feeding opportunists, and thus inputs of allochthonous subsidies indubitably fostered high biomass of these species in the periods of low availability of autochthonous sources of food. Our finding suggests that allochthonous subsidies significantly affect trophic structure and impact both autotrophic and heterotrophic mobilization of energy through food chains in freshwater ecosystems.

Keywords Nutrients - Total organic carbon - Total suspended solids · Phytoplankton · Bacteria · Omnivores 


\section{Introduction}

The European Water Framework Directive, adopted in 2000 , emphasizes the management of freshwaters, which should be achieved through holistic, catchmentscale, ecosystem management approaches. The rate and intensity of in-lake processes are dependent on local catchment conditions; thus, lake catchments should be considered as a complex system of interrelated dependencies. Particulate and dissolved organic and mineral matter is transported within the catchment area and may be accumulated in the lake basins. Thus, the quality of lake water depends on natural factors such as precipitation inputs, erosion and weathering of crustal material, and biota interrelationships, and on anthropogenic influences such as urban, industrial, and agricultural activities (Nõges, 2009; Wan et al., 2014; Moorhouse et al., 2018). Water quality is mainly dependent on the quantity of nutrient loads translocated with water (both as runoff and groundwater recharge). Nutrient retention in lakes has a crucial impact on the ecosystem processes, as nutrients have a limiting effect on the development of aquatic organisms (Elser et al., 2007; Grizzetti et al., 2015). Knowledge of spatial variation of nutrient retention, which is usually positive in winter and negative in summer (Søndergaard et al., 1999), is essential to utilize natural storage capacities more efficiently (Piña-Ochoa \& Álvarez-Cobelas, 2006). Ionic retention is determined as a difference between ionic input and output, and its calculation is considered to be the most accurate approach for the determination of the state of lake ecosystems (Powers et al., 2015).

Most of the research that examines the role of allochthonous inputs in the functioning of lake ecosystems focuses exclusively on allochthonous carbon, as inland waters are considered to play a major role in the global $\mathrm{C}$ cycle. Numerous experiments with ${ }^{13} \mathrm{C}$ addition suggest that allochthonous carbon is incorporated substantially into trophic webs (e.g., Belle et al., 2017). Although allochthonous carbon may enrich the feeding sources of lake organisms (Taipale et al., 2014), it does not fulfill their alimentary requirements, and thus does not have a bearing on the biomass of distinct trophic levels (Brett et al., 2009). Therefore, the significance of terrestrial subsidies, concerned solely as a source of organic carbon, in the support of food webs in autotrophic lakes is regarded as less certain. However, the relative importance of allochthonous resources cannot be discerned from organic carbon budgets alone. Inputs of particulate organic and inorganic matter (assessed in monitoring research as amount of total suspended solids (TSS)) may regulate ecosystem structure, affecting the chemical and physical characteristics of lakes. Both total organic carbon (TOC) and TSS are important sources of phosphorus and nitrogen (Malmaeus \& Håkanson, 2003; Corman et al., 2018) easily available for primary producers (Jones \& Knowlton, 2005). Additionally, detrital particles create a medium for bacterial development. Some studies have reported that half of the bacterioplankton in aquatic ecosystems can be attached to detrital particles (Simon, 1987; Riemann et al., 2000), and thus may be consumed by detritivorous and omnivorous animals. Elevated number of solids in autotrophic lakes autonomizes bacteria to nutrients and thus diminishes the bottom-up control in food web interactions as well as correlates to increased interactions among bacteria and crustaceans that are mainly facultative omnivores (Adamczuk et al., 2015). Decay of organic matter, both during transport and within receiving lake, supplies nutrients easily available for autotrophic producers (Zwart et al., 2015).

Conceptual models on the role of allochthonous inputs of nutrients in functioning of lake ecosystems point out that moderate nutrient addition can affect primary productivity and can lead to bottom-up control of trophic dynamics. That, in turn, might result in longer food chains and higher growth rates of populations (DeAngelis, 1980), whereas high inputs can destabilize food web systems bringing about extinction of top species in a food chain as a result of "the paradox of enrichment" (Rosenzweig, 1971). In this paper, we hypothesize that allochthonous subsidies may affect trophic structure in lakes. When large numbers of terrestrial resources are transferred to lakes, trophic dynamics change. Large variation in the loading of allochthonous subsidies may have considerable effects on the biostructure and productivity of autotrophic lakes. Therefore, in this paper, we focus on the role of allochthonous inputs as a driving force of autotrophic and bacterial production and on how these inputs result in population shifts at higher trophic levels. Our specific hypotheses are as follows:

1. Allochthonous subsidies support phytoplankton production directly by providing nutrients easily 
available for autotrophic organisms and indirectly by loading organic particles available for planktonic omnivores that decrease their predatory impact on phytoplankton.

2. Allochthonous subsidies influence the biomass of bacteria by providing substrata for chemoorganotrophic bacteria and have an indirect effect on heterotrophic nanoflagellates (HNF) which are the main grazers of bacteria.

3. Allochthonous subsidies induce conversions in the structure of trophic webs consisting in increasing diversity and biomass of omnivorous consumers.

\section{Methods}

\section{Study area}

This study was carried out in a small (7.4 ha), shallow (maximum depth $3.1 \mathrm{~m}$ ), flow-through highly eutrophic lake (TSI $_{\mathrm{SD}}$ above 80; Toporowska et al., 2016). We selected that lake to test our hypotheses because previous hydrochemical studies suggest that the lake is characterized by significant fluctuations of ionic loads (Smal et al., 2005, Ferencz et al., 2018), whereas biological studies conducted independently suggest that seasonal changes in autotrophic and heterotrophic plankton weakly correlate with in-lake environmental conditions (Mieczan, 2010; Toporowska \& Pawlik-Skowrońska, 2014). Lake Syczyńskie is situated in eastern Poland $\left(51^{\circ} 17^{\prime} 12^{\prime \prime} \mathrm{N}\right.$, $\left.23^{\circ} 14^{\prime} 17^{\prime \prime} \mathrm{E}\right)$. The lake is located at $179 \mathrm{~m}$ a.s.l. and occupies $2.66 \mathrm{~km}^{2}$ catchment area. The catchment is dual in nature in terms of relief. A part adjacent to the lake basin, which belongs to the physiographical region of Polesie, is flat (up to $3.5 \mathrm{~m}$ denivelations), whereas the eastern parts of the catchment, belonging to the physiographical units of Chełm Hills, are elevated over $220 \mathrm{~m}$ a.s.l. The denivelations of the catchment are up to $46 \mathrm{~m}$. The lake is supplied with water from four tributaries: one episodic, one perennial, and two intermitted. Lake Syczyńskie is drained southwest, toward the Świnka River (Fig. 1). Agricultural lands consist more than $80 \%$ of the catchment area. Lake Syczyńskie is characterized by intensive development of emergent vegetation, dominated by reed (Phragmites australis (Cav.) Trin. ex Steud.) and temporal blooms of Planktothrix agardhii (Gomont) (Toporowska \& Pawlik-Skowrońska, 2014).

Field studies

The studies were conducted every fortnight, in two consecutive hydrological years, from November 1, 2015 to October 31, 2017. The flow rates, as well as total phosphorus (TP), dissolved ortho-phosphorus $\left(\mathrm{P}-\mathrm{PO}_{4}\right)$, nitrate nitrogen $\left(\mathrm{N}-\mathrm{NO}_{3}\right)$, ammonium nitrogen $\left(\mathrm{N}-\mathrm{NH}_{4}\right), \mathrm{TOC}$, and TSS, were measured twice a month in both the inlets and the outlet of the lake (Fig. 1). The flow rates were estimated using an OTT Nautilus 2000 flow meter. TOC and TSS were measured using a PASTEL UV spectrophotometer (Secomam, France). All the analyses of phosphorus were performed according to the PN-EN ISO 6878 procedure (2006). TP was measured in $40 \mathrm{ml}$ samples acidified with $4.5 \mathrm{M} \mathrm{H}_{2} \mathrm{SO}_{4}$ and mineralized with addition of $5 \% \mathrm{~K}_{2} \mathrm{~S}_{2} \mathrm{O}_{8}$. The mineralizate with $10 \%$ $\mathrm{C}_{6} \mathrm{H}_{8} \mathrm{O}_{6}$ and $\left(\mathrm{NH}_{4}\right)_{6} \mathrm{Mo}_{7} \mathrm{O}_{24}$ was analyzed spectrophotometrically. $\mathrm{P}-\mathrm{PO}_{4}$ was measured spectrophotometrically in $40 \mathrm{ml}$ samples after filtration by $0.45 \mu \mathrm{m}$ filters and addition of $10 \% \mathrm{C}_{6} \mathrm{H}_{8} \mathrm{O}_{6}$ and $\left(\mathrm{NH}_{4}\right)_{6-}$ $\mathrm{Mo}_{7} \mathrm{O}_{24} \cdot 4 \mathrm{H}_{2} \mathrm{O}$. N-NO $\mathrm{NO}_{3}$ was measured by the sodium salicylate method: $10 \mathrm{ml}$ water samples with $1 \mathrm{ml}$ sodium salicylate were evaporated, and the evaporate was measured spectrophotometrically after addition of concentrated $\mathrm{H}_{2} \mathrm{SO}_{4}$ and $\mathrm{NaOH}$. The analyses of TP, $\mathrm{P}-\mathrm{PO}_{4}$, and $\mathrm{N}-\mathrm{NO}_{3}$ were performed with the use of a Shimadzu UV-1610 spectrophotometer. $\mathrm{N}^{-\mathrm{NH}_{4}}$ was measured by Kjeldahl method according to the PN ISO 7150 procedure $(2002 \mathrm{a}, \mathrm{b})$ : the samples were heated with $\mathrm{H}_{2} \mathrm{SO}_{4}$ and distilled by adding $\mathrm{NaOH}$, after which the distillate was trapped in boric acid solution and the quantity of ammonia was determined by back titration.

Load of external nutrients, TOC, and TSS was calculated as follows:

$L=C \cdot Q$

where $L$ is the load, $C$ is the concentration in stream water, and $Q$ is the discharge of the stream.

Retention of nutrients, TOC, and TSS was calculated as

$R x=\left(L x_{\text {in }}-L x_{\text {out }}\right) / L x_{\text {in }}$ 

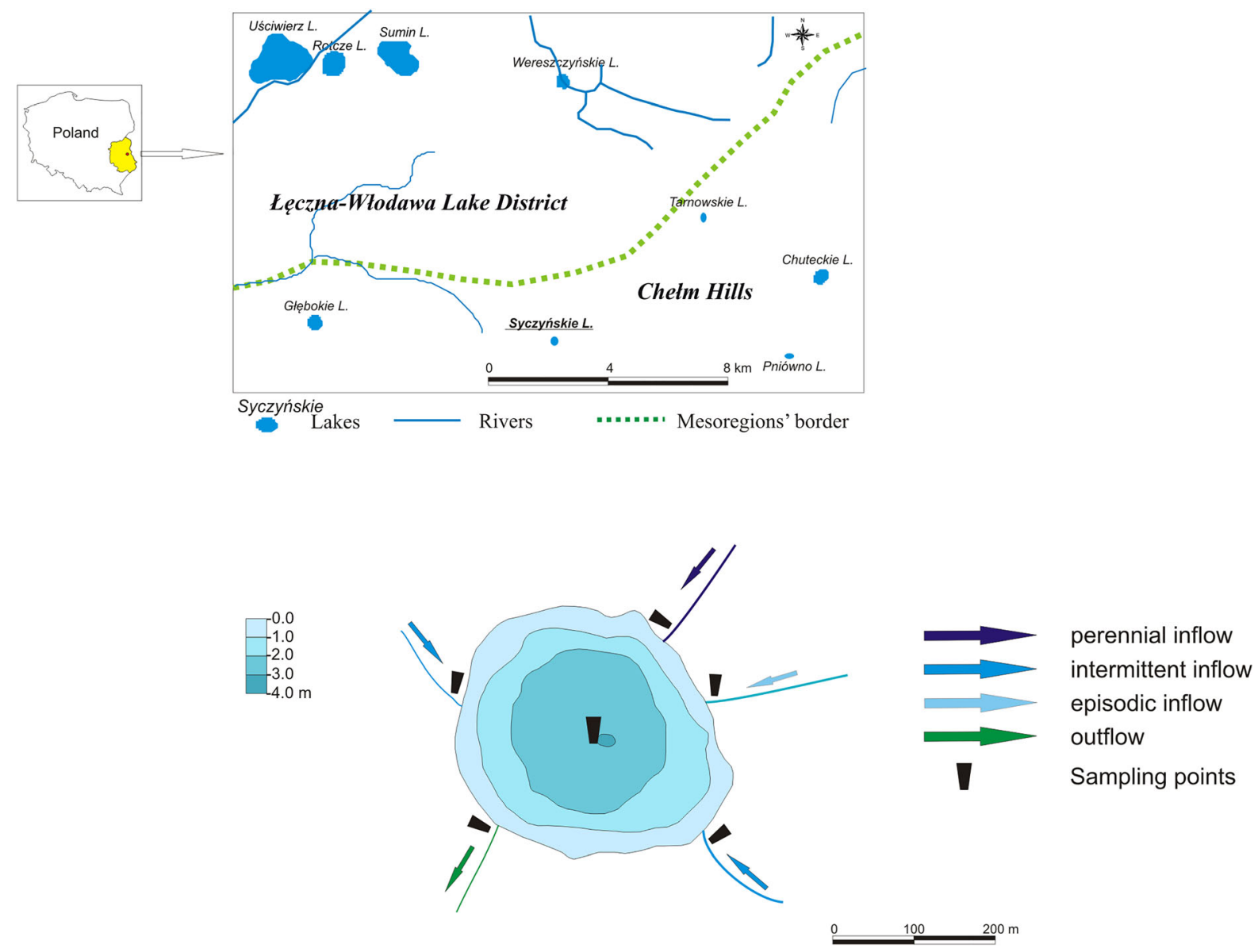

Fig. 1 Study area and bathymetric scan of the Lake Syczyńskie

where $R x$ is the retention of an $x, L x_{\text {in }}$ is an input loading rate, and $L x_{\text {out }}$ is an output loading rate. For this study, $L x_{\text {in }}$ was considered as a sum of input load of all the four tributaries. Positive or negative retention indicated ion accumulation in or removal from the system. $R x$ values resulting from differences between output and input of nutrients, TOC, and TSS were considered as amounts of allochthonous subsidies. Difference between nutrients and matter that exits the lake basin and input from the catchment reflected the intensity of in-lake (autochthonous) processes. Higher nutrients and matter output than input from the catchment may have resulted from in-lake enrichment (autochthonous production of the lake).

Collection of plankton samples (chlorophyll-a (chla), bacteria, HNF, ciliates, crustaceans) as well as physical and chemical measurements was performed in the central part of the lake (Fig. 1). All the samples and measurements were taken vertically in the water column, every $0.5 \mathrm{~m}$ depth, and the results were averaged for each date of sampling. Temperature, dissolved oxygen (DO), electrical conductivity (EC), and $\mathrm{pH}$ were determined in situ with a YSI 556 MPS multiparametric probe. A volume of $0.2-11$ of water was collected to determine the phytoplankton chl-a. According to the PN ISO 10260 procedure (2002), water was filtered by GF/C Whatman filters, which was later extracted for $5 \mathrm{~min}$ in $90 \%$ ethanol in a water bath at $75^{\circ} \mathrm{C}$. After the collection of supernatants, chla was analyzed spectrophotometrically (Specord 40 Analytik Jena). The analysis of chl-a was performed in two replicates. Concentration of chl-a was used as a proxy to estimate the biomass of phytoplankton (Huont et al., 2007). The abundance and biomass of bacteria and HNF were determined with 4',6-diamino2-phenylindole (Porter \& Feig, 1980). A $10 \mathrm{ml}$ 
volume of water was preserved in formaldehyde to a final concentration of $2 \%$ and kept in darkness at $4{ }^{\circ} \mathrm{C}$. Preparations were made within $24 \mathrm{~h}$ of sampling. Subsamples of $2 \mathrm{ml}$ were condensed on polycarbonate filters $(0.2 \mu \mathrm{m}$ pore size $)$ dyed with Irgalan black and enumerated by an epifluorescence microscope. Ciliata communities were investigated using a $5 \mathrm{dm}^{3}$ planktonic sampler. Three replicate samples of a volume of $0.5 \mathrm{dm}^{3}$ were fixed with Lugol's solution $(0.2 \%$ final concentration). Densities of ciliates were determined with an inverted microscope by the settling chamber technique: $50 \mathrm{ml}$ of sample was sedimented for at least $24 \mathrm{~h}$, and half of the bottom of the chamber was counted at $\times 300$ magnification (Utermöhl, 1958). Biomass of bacteria and HNF was estimated by assuming geometric shapes and converting to carbon using the following conversion factors: bacteria: $1 \mu \mathrm{m}^{3}=5.6 \times 10^{-7} \quad \mathrm{mgC} ; \quad \mathrm{HNF}: \quad 1 \mu \mathrm{m}^{3-}$ $=1.1 \times 10^{-7} \mathrm{mgC}$ (Gilbert et al., 1998). Ciliate biomass was estimated by multiplying the numerical abundance by the mean cell volume $\left(1 \mu \mathrm{m}^{3}=1 \mathrm{pg}\right)$ calculated from direct volume measurements using appropriate geometric formulas (Finlay, 1982). Prior to calculation, cell volumes were multiplied by a correction factor of 0.4 (Jerome et al., 1993). Sample of crustacean plankton was collected with the use of a $5 \mathrm{dm}^{3}$ sampler. Double samples were taken every $0.5 \mathrm{~m}$ depth and pooled to reduce heterogeneity in metazooplankton distribution and sampling variability, so that the final volume of each sample measured $10 \mathrm{dm}^{3}$. Samples were sieved through a $40-\mu \mathrm{m}$-mesh net and fixed with Lugol's solution. Cladocera and Copepoda species were classified and counted using a Sedgewick-Rafter chamber. Estimation of crustacean biomass was based on the correlations between the body length and body mass and was conducted using established mathematical formulas (Dumont et al., 1975; Bottrell et al., 1976; Culver et al., 1985).

Data analysis and testing of hypotheses

Prior to analysis, all the data were $z$-mean standardized to fix normal distribution. To test the first two hypotheses, we used stepwise multiple linear regression (SMLR), and for the third hypothesis, we used multivariate analyses.

Hypothesis 1 Allochthonous subsidies versus phytoplankton.
To test whether the amount of phytoplankton $p$ in time $t$ changed with allochthonous subsidies of available nutrients $b$, namely TP, $\mathrm{P}-\mathrm{PO}_{4}, \mathrm{~N}-\mathrm{NO}_{3}$, and $\mathrm{N}-\mathrm{NH}_{4}$, we derived nutrient-limited ecosystem model with exploitation ecosystem dynamics (Oksanen et al., 1981). Thus, we described $p_{t}$ as $b$-model:

$$
\begin{aligned}
b_{t}= & \beta_{t}+y_{1} \cdot(\mathrm{TP})_{t}+y_{2} \cdot\left(\mathrm{P}-\mathrm{PO}_{4}\right)_{t} \\
& +y_{3} \cdot\left(\mathrm{N}-\mathrm{NO}_{3}\right)_{t}+y_{4} \cdot\left(\mathrm{N}-\mathrm{NH}_{4}\right)_{t}+\text { error }
\end{aligned}
$$

Although we observed values directly for $b$, we also parameterized assimilability of nutrients $\zeta b$ as variable dependent on availability of phytoplanktonic organisms to absorb nutrients, which is regulated by transparency, $\mathrm{pH}$, and temperature of water. We excluded water transparency as independent variable of $\zeta b$ because the studied lake was noncolored and shallow enough to be entirely penetrated by light, and water transparency was rather correlated to the amount of phytoplankton particles. Thus, we modeled $b+\zeta b$ as

$$
\begin{aligned}
b_{t}+\zeta b_{t}= & \beta_{\mathrm{t}}+y_{1} \cdot(\mathrm{TP})_{t}+y_{2} \cdot\left(\mathrm{P}-\mathrm{PO}_{4}\right)_{t} \\
& +\mathrm{y}_{3} \cdot\left(\mathrm{N}-\mathrm{NO}_{3}\right)_{t}+\mathrm{y}_{4} \cdot\left(\mathrm{N}-\mathrm{NH}_{4}\right)_{t} \cdot \\
& +y_{5} \cdot\left[(\mathrm{TP})_{t} \times \mathrm{temp}_{t}\right]+y_{6} \cdot\left[(\mathrm{TP})_{t} \times \mathrm{pH}_{t}\right] \\
& +y_{7} \cdot\left[\left(\mathrm{P}-\mathrm{PO}_{4}\right)_{t} \times \mathrm{temp}_{t}\right] \\
& +y_{8} \cdot\left[\left(\mathrm{P}-\mathrm{PO}_{4}\right)_{t} \times \mathrm{pH}_{t}\right] \\
& +y_{9} \cdot\left[\left(\mathrm{N}-\mathrm{NO}_{3}\right)_{t} \times \mathrm{temp}_{t}\right] \\
& +y_{10} \cdot\left[\left(\mathrm{N}-\mathrm{NO}_{3}\right)_{t} \times \mathrm{pH}_{t}\right] \\
& +y_{11} \cdot\left[\left(\mathrm{N}-\mathrm{NH}_{4}\right)_{t} \times\right. \text { temp } \\
& +y_{12} \cdot\left[\left(\mathrm{N}-\mathrm{NH}_{4 t}\right)+\mathrm{error}\right]
\end{aligned}
$$

We also hypothesized that allochthonous organic particles diversified food resource for planktonic omnivores and thus diminished their predatory pressure on phytoplankton. During the whole study period, omnivorous ciliates were represented by 11 taxa. Ultimately, six taxa (Bursellopsis sp. Corliss, 1960, Dileptus margaritifer (Ehrenberg, 1838), Vorticella campanula (Ehrenberg, 1831), Paramecium bursaria (Ehrenberg, 1831), Strombidium viride (Stein, 1867), Halteria grandinella (Müller, 1773), Coleps hirtus (Müller, 1786)) fulfilled the assumptions of the SMLR analysis. Species richness of omnivorous crustaceans was quite low, for they were represented only by two species of Cladocera (Bosmina longirostris (O. F. 
Müller, 1785) and Daphnia galeata $\times$ longispina) and one species of Copepoda (Eudiaptomus graciloides (Liljeborg, 1888)) as well as larval- and juvenile-stage Copepoda (nauplii and copepodites, respectively), which are also omnivores. Bosmina, Daphnia, Eudiaptomus, and nauplii fulfilled the assumptions of the SMLR analysis. Copepodites also fulfilled the assumptions of the SMLR analysis, but we decided to include only Calanoida copepodites in the analysis and omit Cyclopoida copepodites, for some $\mathrm{V}$-stage Cyclopoida copepodites are facultative predators, and thus may blur the results of the analyses. To find the role of allochthonous matter as a food source diminishing feeding pressure of omnivores on phytoplankton (phyt), we modeled $I_{t}$ as

$I_{t}=\beta_{t}+y_{1} \cdot \mathrm{TSS}_{t}+y_{2} \cdot \mathrm{TOC}_{t}+y_{3} \cdot \mathrm{phyt}_{t}+$ error

However, as there are assumptions that grazing of omnivores is affected by abiotic variables (Adamczuk et al., 2015), we also computed $I+\xi I$-model, in which we searched for relationships between biomass of omnivores and variables used in Eq. 3 related to temperature, $\mathrm{pH}, \mathrm{EC}$, and DO. Thus, our $I+\xi I$-model was

$$
\begin{aligned}
& I_{t}+\xi I_{t}=\beta_{t}+\mathrm{y}_{1} \cdot \mathrm{TSS}_{t}+y_{2} \cdot \mathrm{TOC}_{t}+y_{3} \cdot \mathrm{phyt}_{t} \\
& +y_{4} \cdot\left[\mathrm{TSS}_{t} \times \mathrm{pH}_{t}\right]+y_{5} \cdot\left[\mathrm{TSS}_{t} \times \text { temp }_{t}\right] \\
& +y_{6} \cdot\left[\mathrm{TSS}_{t} \times \mathrm{EC}_{t}\right]+y_{7} \cdot\left[\begin{array}{ll}
\mathrm{TSS}_{t} \times \mathrm{DO}_{t}
\end{array}\right] \\
& +y_{8} \cdot\left[\mathrm{TOC}_{t} \times \mathrm{pH}_{t}\right]+y_{9} \cdot\left[\mathrm{TOC}_{t} \times \text { temp }_{t}\right]
\end{aligned}
$$

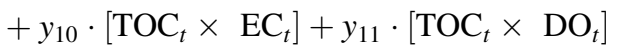

$$
\begin{aligned}
& +y_{12} \cdot\left[\mathrm{phyt}_{t} \times \mathrm{pH}_{t}\right]+y_{13} \cdot\left[\mathrm{phyt}_{t} \times \text { temp }_{t}\right] \\
& +y_{14} \cdot\left[\mathrm{phyt}_{t} \times \mathrm{EC}_{t}\right]+y_{15} \cdot\left[\mathrm{phyt}_{t} \times \mathrm{DO}_{\mathrm{t}}\right] \\
& + \text { error }
\end{aligned}
$$

Hypothesis 2 Allochthonous subsidies versus bacteria and HNF.

To test whether the biomass of microorganisms $(M)$ in time $t$ changed with subsidies of allochthonous matter, we used a model for population dynamics in a stochastic environment derived by Roughgarden (1975). Thus, we computed $M$-model as
$M_{t}=\beta_{t}+y_{1} \cdot \mathrm{TSS}_{t}+y_{2} \cdot \mathrm{TOC}_{t}+y_{3} \cdot \mathrm{phyt}_{t}+$ error

We also computed $M+\xi M$-model, in which we searched for linear relationships between biomass of microorganisms and variables used in Eq. 5 related to temperature, $\mathrm{pH}, \mathrm{EC}$, and DO. Thus, our $I+\xi I$-model was

$$
\begin{aligned}
& M_{t}+\xi M_{t}=\beta_{t}+y_{1} \cdot \mathrm{TSS}_{t}+y_{2} \cdot \mathrm{TOC}_{t} \\
& +y_{3} \cdot \mathrm{chl}-a_{t}+y_{4} \cdot\left[\mathrm{TSS}_{t} \times \mathrm{pH}_{t}\right] \\
& +y_{5} \cdot\left[\mathrm{TSS}_{t} \times \mathrm{temp}_{t}\right]+y_{6} \cdot\left[\mathrm{TSS}_{t} \times \mathrm{EC}_{t}\right] \\
& +y_{7} \cdot\left[\mathrm{TSS}_{t} \times \mathrm{DO}_{t}\right]+y_{8} \cdot\left[\mathrm{TOC}_{t} \times \mathrm{pH}_{t}\right] \\
& +y_{9} \cdot\left[\mathrm{TOC}_{t} \times \text { temp }_{t}\right]+y_{10} \cdot\left[\mathrm{TOC}_{t} \times \mathrm{EC}_{t}\right] \\
& +y_{11} \cdot\left[\mathrm{TOC}_{t} \times \mathrm{DO}_{t}\right]+y_{12} \cdot\left[\mathrm{phyt}_{t} \times \mathrm{pH}_{t}\right] \\
& +y_{13} \cdot\left[\text { phyt }_{t} \times \text { temp }_{t}\right]+y_{14} \cdot\left[\mathrm{phyt}_{t} \times \mathrm{EC}_{t}\right] \\
& +y_{15} \cdot\left[\mathrm{phyt}_{t} \times \mathrm{DO}_{t}\right]+\text { error }
\end{aligned}
$$

We included chl-a in the above models, for alive cells of phytoplankton may compete with bacteria for nutrients, whereas the mass of perished phytoplanktonic cells may constitute a substratum to be utilized by bacteria. We computed the above models for bacteria and HNF separately.

Variance inflation factors were calculated to eliminate collinearity among the main independent variables in the first phase of modeling. Akaike information criterion (AIC) was employed to determine which combination of variables resulted in the most parsimonious models for predicting the hypotheses. In the final models, the strengths of relationships among dependent and independent variables were tested with the use of partial correlations $\left(r_{\text {part }}\right)$.

Hypothesis 3 Allochthonous subsidies versus trophic structure.

To test whether allochthonous subsidies induce conversions in the structure of trophic webs consisting in increasing diversity and biomass of omnivorous consumers, we applied multivariate analyses. The variability gradients indicated by ciliates and crustaceans were measured using detrended correspondence analysis. As the lengths of both the gradients were $<2$ standard deviation, redundancy analysis (RDA) was used to explore the relationships between the density of omnivorous Ciliata and Crustacea species and allochthonous TOC and TSS versus phytoplankton and bacterioplankton. Temperature, 
$\mathrm{pH}, \mathrm{EC}$, and $\mathrm{DO}$ were included in the analysis as covariables (terBraak \& Smilauer, 2002). Automatic forward selection of environmental variables (Monte Carlo permutation test) was used to determine the significant food sources $(P<0.05)$ that are presented as bold arrows in the diagrams. The proportion of variance explained by particular food sources was quantified using variance partitioning. The analysis was performed separately for Ciliata and Crustacea species in CANOCO 4.5 for Windows.

\section{Results}

\section{Allochthonous subsidies versus phytoplankton}

The variance inflation factor for $\mathrm{N}-\mathrm{NH}_{4}$ was calculated as 3.32 indicating collinearity between that variable and other covariates; therefore, $\mathrm{N}-\mathrm{NH}_{4}$ was excluded from $b$ - and $b+\zeta b$-model. Sufficient data (outlier cases were removed from the analysis) were available to develop nutrient models for phytoplankton. Ultimately, two variables, including allochthonous $\mathrm{N}-\mathrm{NO}_{3}$ and $\mathrm{P}-\mathrm{PO}_{4}$, were included in the $b$-model $(\mathrm{AIC}=9.133)$. Altogether, the variables explained more than a half of variance in phytoplankton biomass (adjusted $R^{2}=0.612$ ), but only allochthonous $\mathrm{N}-\mathrm{NO}_{3}$ displayed significant interactions with phytoplankton biomass (Table 1). As might be expected, $b+\zeta b$ model performed better than $b$-model (adjusted $R^{2}=0.806$ ). Among the 12 variables tested, four were included in the model, including $\mathrm{N}-\mathrm{NO}_{3}, \mathrm{~N}-\mathrm{NO}_{3}$ $\times \mathrm{pH}, \quad \mathrm{P}-\mathrm{PO}_{4} \times \mathrm{pH}, \quad$ and $\mathrm{P}-\mathrm{PO}_{4} \times$ temperature $(\mathrm{AIC}=6.894)$. The model revealed that $\mathrm{N}-\mathrm{NO}_{3}$ and $\mathrm{P}-\mathrm{PO}_{4} \times$ temperature showed positive relation to biomass of phytoplankton, whereas $\mathrm{N}-\mathrm{NO}_{3} \times \mathrm{pH}$, $\mathrm{P}-\mathrm{PO}_{4} \times \mathrm{pH}$ negatively influenced phytoplankton biomass. Partial correlations displayed that allochthonous $\mathrm{N}-\mathrm{NO}_{3}$ and allochthonous $\mathrm{P}-\mathrm{PO}_{4} \times \mathrm{pH}$ had the most significant influence on the development of phytoplankton (Table 1). We also modeled the effect of phytoplankton, allochthonous TOC, and allochthonous TSS on the biomass of omnivores to estimate whether allochthonous sources of food diminish the role of phytoplankton as a food source for omnivores. Values of the variance inflation factor for these variables were lower than 2 indicating low collinearity. In this case, we also applied two models: without - and with interactions with abiotic variables. I-model (without interactions) performed well in

Table 1 Coefficients of structural models predicting effects of allochthonous nutrients on the development of phytoplankton

\begin{tabular}{|c|c|c|c|c|c|c|c|c|}
\hline \multirow[t]{2}{*}{ Var. included into the model } & \multicolumn{4}{|c|}{$\begin{array}{l}b \text {-model } \\
R^{2}=0.643, \text { adj. } R^{2}=0.612 \\
\beta=0.790, P=0.00003\end{array}$} & \multicolumn{4}{|c|}{$\begin{array}{l}b+\zeta b \text { - model } \\
R^{2}=0.863, \text { adj. } R^{2}=0.806 \\
\beta=-0.674, P=0.0005\end{array}$} \\
\hline & $y$ & $P$ & $r_{\text {part }}$ & $P$ & $y$ & $P$ & $r_{\text {part }}$ & $P$ \\
\hline all. TP & - & - & - & - & - & - & - & - \\
\hline all. $\mathrm{P}-\mathrm{PO}_{4}$ & 0.336 & 0.013 & 0.33 & 0.13 & - & - & - & - \\
\hline all. $\mathrm{N}-\mathrm{NO}_{3}$ & 0.836 & 0.00002 & 0.60 & 0.003 & 4.888 & 0.039 & 0.32 & 0.012 \\
\hline all. $\mathrm{N}-\mathrm{NH}_{4}$ & ex & ex & ex & ex & ex & ex & ex & ex \\
\hline all. $\mathrm{TP} \times \mathrm{pH}$ & ne & ne & ne & ne & - & - & - & - \\
\hline all. TP $\times$ temp & ne & ne & ne & ne & - & - & - & - \\
\hline all. $\mathrm{P}-\mathrm{PO}_{4} \times \mathrm{pH}$ & ne & ne & ne & ne & -3.926 & 0.010 & -0.21 & 0.078 \\
\hline all. $\mathrm{P}-\mathrm{PO}_{4} \times$ temp & ne & ne & ne & ne & 0.631 & 0.021 & 0.10 & 0.376 \\
\hline all. $\mathrm{N}-\mathrm{NO}_{3} \times \mathrm{pH}$ & ne & ne & ne & ne & -1.337 & 0.018 & -0.41 & 0.002 \\
\hline all. $\mathrm{N}-\mathrm{NO}_{3} \times$ temp & ne & ne & ne & ne & ex & ex & ex & ex \\
\hline all. $\mathrm{N}-\mathrm{NH}_{4} \times \mathrm{pH}$ & ne & ne & ne & ne & ex & ex & ex & ex \\
\hline all. $\mathrm{N}-\mathrm{NH}_{4} \times$ temp & ne & ne & ne & ne & ex & ex & ex & ex \\
\hline
\end{tabular}

$b$-model includes nutrients without interactions with abiotic parameters; $b+\zeta b$-model includes nutrients interacted with abiotic parameters; - means slope not provided for Akaike information criterion; ex excluded due to variance inflation factor $>2$; ne not evaluated; all. allochthonous 
Table 2 Coefficients of structural models predicting effects of different sources of food on the development of omnivore species

\begin{tabular}{|c|c|c|c|c|c|c|c|c|}
\hline \multirow[t]{2}{*}{ Var. included into the model } & \multicolumn{4}{|c|}{$\begin{array}{l}I \text {-model } \\
R^{2}=0.942, \text { adj. } R^{2}=0.730 \\
\beta=0.107, P=0.015\end{array}$} & \multicolumn{4}{|c|}{$\begin{array}{l}I+\xi I \text {-model } \\
R^{2}=0.920, \text { adj. } R^{2}=0.845 \\
\beta=-5.623, P=0.0001\end{array}$} \\
\hline & $y$ & $P$ & $r_{\text {part }}$ & $P$ & $y$ & $P$ & $r_{\text {part }}$ & $P$ \\
\hline all. TSS & 0.159 & 0.174 & 0.21 & 0.063 & - & - & - & - \\
\hline all. TOC & 0.86 & 0.000002 & 0.54 & 0.008 & 6.183 & 0.0009 & 0.84 & 0.001 \\
\hline phyt & 0.42 & 0.00003 & 0.391 & 0.041 & 4.088 & 0.0001 & 0.91 & 0.0001 \\
\hline all. TSS $\times \mathrm{pH}$ & ne & ne & ne & ne & 7.088 & 0.0001 & 0.71 & 0.014 \\
\hline all. TSS $\times$ temp & ne & ne & ne & ne & 1.429 & 0.0005 & 0.87 & 0.00004 \\
\hline all. TSS $\times \mathrm{EC}$ & ne & ne & ne & ne & - & - & - & - \\
\hline all. TSS $\times$ DO & ne & ne & ne & ne & - & - & - & - \\
\hline all. TOC $\times$ pH & ne & ne & ne & ne & 0.233 & 0.007 & 0.75 & 0.009 \\
\hline all. TOC $\times$ temp & ne & ne & ne & ne & -2.519 & 0.0001 & -0.91 & 0.0001 \\
\hline all. TOC $\times$ EC & ne & ne & ne & ne & 2.963 & 0.054 & 0.59 & 0.051 \\
\hline all. $\mathrm{TOC} \times \mathrm{DO}$ & ne & ne & ne & ne & - & - & - & - \\
\hline phyt $\times$ pH & ne & ne & ne & ne & -2.269 & 0.076 & -0.55 & 0.082 \\
\hline phyt $\times$ temp & ne & ne & ne & ne & 0.907 & 0.002 & 0.59 & 0.023 \\
\hline phyt $\times$ EC & ne & ne & ne & ne & - & - & - & - \\
\hline phyt $\times$ DO & ne & ne & ne & ne & - & - & - & - \\
\hline
\end{tabular}

$I$-model includes nutrients without interactions with abiotic parameters; $I+\xi I$-model includes nutrients interacted with abiotic parameters; - means slope not provided for Akaike information criterion, ne not evaluated, all. allochthonous

predicting the role of food source, with adjusted $R^{2}=0.730$. The AIC values retained all the variables in this model (AIC $=8.469)$. The model demonstrated the ascendant role of allochthonous TOC over phytoplankton and the insignificant role of allochthonous TSS as a food source (Table 2). $I+\xi I$-model performed better than model without interactions, but the improved performance was generally modest with an increase of adjusted $R^{2}$ to a value of 0.845 . The model confirmed the relationships between omnivores and allochthonous TOC versus phytoplankton and demonstrated that TOC in interaction with EC positively influenced the biomass of omnivores. Temperature and $\mathrm{pH}$ displayed a twofold impact. Temperature had a positive effect on biomass of omnivores when interacted with phytoplankton and allochthonous TSS but negatively impacted omnivores when interacted with allochthonous TOC, whereas $\mathrm{pH}$ had a negative impact on omnivores when interacted with phytoplankton and a positive impact when interacted with allochthonous TSS and TOC (Table 2).
Allochthonous subsidies versus bacteria and HNF

Values of the variance inflation factor for variables evaluated in $M$ - and $M+\xi M$-models were lower than 2 indicating low collinearity. In $M$-model, AIC criterion retained only allochthonous TSS and phytoplankton to improve the model fit (bacteria: AIC = 21.485, HNF: AIC $=31.662$ ). Results of the model revealed that phytoplankton and allochthonous TSS influenced the development of bacteria and HNF, and the coefficients of the model suggested that phytoplankton competed with bacteria for subsidies and thus indirectly influenced the biomass of $\mathrm{HNF}$ (Table 3). $M+\xi M$-model significantly improved adjusted $R^{2}$ for bacteria ( $M$-model: adjusted $R^{2}=0.400, M+\xi M$-model: adjusted $R^{2}=0.648$ ) and pointed out the role of abiotic variables in availability of allochthonous sources of food. Allochthonous TOC had a positive effect on bacteria only when interacted with $\mathrm{pH}$. Interestingly, $M+\xi M$ model revealed that phytoplankton when interacted with $\mathrm{pH}$, temperature, and DO showed negative correlations with bacteria, but in interaction with EC 
Table 3 Coefficients of structural models predicting effects of different sources of food on the development of bacteria and HNF

\begin{tabular}{|c|c|c|c|c|c|c|c|c|}
\hline \multirow[t]{3}{*}{ Var. included into the model } & \multicolumn{4}{|l|}{ Bacteria } & \multicolumn{4}{|l|}{ HNF } \\
\hline & \multicolumn{4}{|c|}{$\begin{array}{l}M \text {-model } \\
R=0681, R^{2}=0463, \text { adj. } R^{2}=0.400 \\
\beta=0.429, P=0.003\end{array}$} & \multicolumn{4}{|c|}{$\begin{array}{l}M \text {-model } \\
R=0.855, R^{2}=0.731, \text { adj. } R^{2}=0.713 \\
\beta=0.356, P=0.002\end{array}$} \\
\hline & $y$ & $P$ & $r_{\text {part }}$ & $P$ & $y$ & $P$ & $r_{\text {part }}$ & $P$ \\
\hline phyt & -0.58 & 0.005 & -0.52 & 0.021 & -0.855 & 0.00001 & -0.35 & 0.043 \\
\hline all. TSS & & & & & 0.488 & 0.007 & 0.31 & 0.055 \\
\hline all. TOC & - & - & - & - & - & - & - & - \\
\hline \multirow[t]{2}{*}{ Var. included into the model } & \multicolumn{4}{|c|}{$\begin{array}{l}I+\xi M \text {-model } \\
R=0.869, R^{2}=0.755, \text { adj. } R^{2}=0.648 \\
\beta=0.429, P=0.003\end{array}$} & \multicolumn{4}{|c|}{$\begin{array}{l}I+\xi M \text {-model } \\
R=0.543, R^{2}=0.295, \text { adj. } R^{2}=0.189 \\
\beta=0.429, P=0.003\end{array}$} \\
\hline & $y$ & $P$ & $r_{\text {part }}$ & $P$ & $y$ & $P$ & $r_{\text {part }}$ & $P$ \\
\hline phyt & -0.248 & 0.07 & -0.43 & 0.029 & -0.381 & 0.06 & -0.40 & 0.066 \\
\hline all. TSS & - & - & - & - & 0.423 & 0.03 & 0.52 & 0.027 \\
\hline all. TSS $\times$ temp & - & - & - & - & 0.319 & 0.279 & 0.24 & 0.279 \\
\hline all. TOC $\times \mathrm{pH}$ & 0.400 & 0.02 & 0.54 & 0.021 & - & - & - & - \\
\hline all. TOC $\times$ temp & - & - & - & - & -0.436 & 0.148 & -0.32 & 0.148 \\
\hline phyt $\times$ pH & -3.120 & 0.009 & -0.59 & 0.009 & - & - & - & - \\
\hline phyt $\times$ temp & -0.351 & 0.113 & -0.39 & 0.122 & - & - & - & - \\
\hline phyt $\times$ EC & 3.943 & 0.00007 & 0.80 & 0.0007 & - & - & - & - \\
\hline phyt $\times$ DO & -0.643 & 0.507 & -0.167 & 0.507 & - & - & - & - \\
\hline
\end{tabular}

$M$-model includes food sources without interactions with abiotic parameters; $M+\xi I$-model includes food sources interacted with abiotic parameters; - means slope not provided for Akaike information criterion; all. allochthonous

it showed positive relationships with bacteria. $M+\xi M$-model computed for HNF pointed out temperature as an important variable influencing the availability of allochthonous sources; however, model with interactions performed worse than model without interactions ( $M$-model: adjusted $R^{2}=0.713$, $M+\xi M$-model: adjusted $\left.R^{2}=0.189\right)$. Both models suggested that HNF displayed positive relationships with allochthonous TSS and negative relationships with phytoplankton, which was also confirmed by the values of partial correlations (Table 3).

Allochthonous subsidies versus trophic structure

Redundancy analysis performed to specify the direct effect of different food sources on biomass of omnivorous Ciliata and Crustacea showed that all canonical axes explained $32.8 \%$ of total variance of omnivorous Ciliata and $61.9 \%$ of total variance of omnivorous Crustacea. Permutation test performed for omnivorous Ciliata showed that all the food sources had an insignificant effect on Ciliata, and explained from $1 \%$ (allochthonous TSS) to 26\% (phytoplankton) of total variance of Ciliata. On the RDA biplot, the biomass of $P$. bursaria was affected by TOC, whereas the biomass of Bursellopsis sp. and S. viride increased together with the biomass of bacteria. The length of the variability gradient and position on the graph of $V$. campanula suggested that the species contributed significantly to the total biomass of Ciliata incorporated in the analysis, but its biomass was affected by all the food sources (Fig. 2A). The rest of the species that were included in the analysis gathered in the intersections of axis 1 and axis 2 suggesting the insignificant influence of the analyzed food sources on their biomass. Thus, they were not presented in the biplot diagram. Permutation test performed for Crustacea showed the significant role of allochthonous TOC $(F=18.2, P=0.006)$ that explained $45 \%$ of their total variance and phytoplankton that explained $8 \%$ of their total variance in that group $(F=3.31$, $P=0.048)$. On the RDA biplot, the biomass of $B$. 


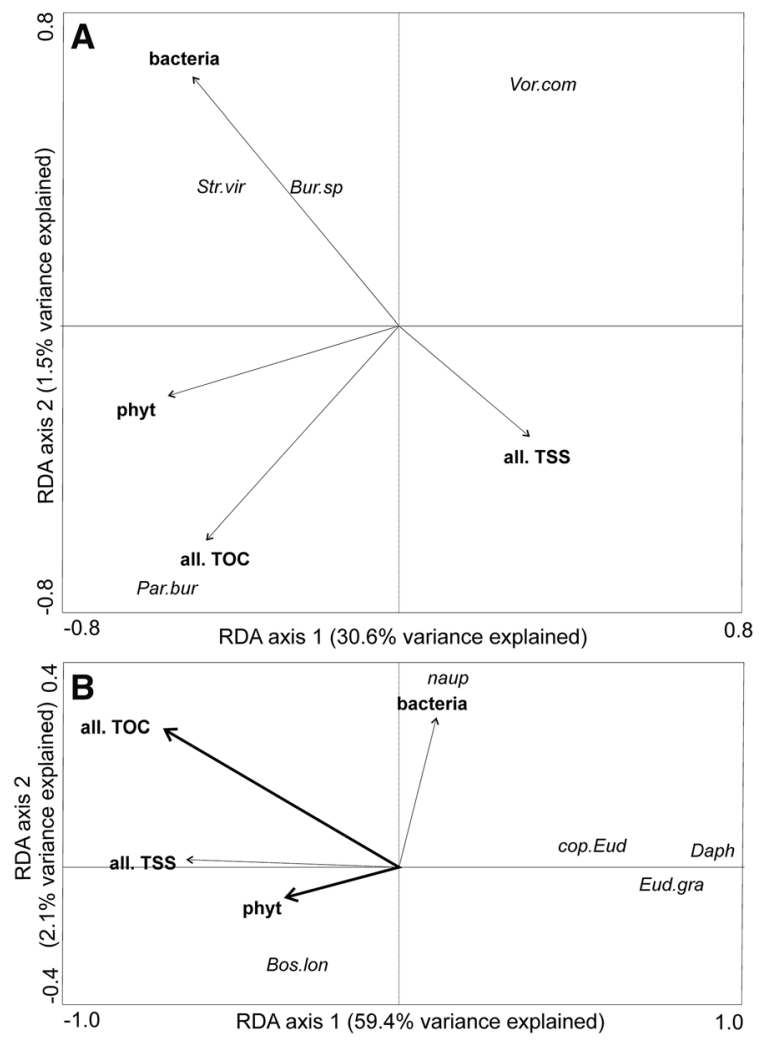

Fig. 2 Redundancy analysis (RDA) showing distribution of Ciliata (A) and Crustacea (B) biomass in relation to allochthonous and autochthonous food sources. Species codes: Bos.lon, Bosmina longirostris; Bur.sp, Bursellopsis sp.; cop.Eud, copepodites of Eudiaptomus graciloides; Daph, Daphnia galeata $\times$ longispina; Eud.gra, E. graciloides; naup, nauplii; Par.bur, Paramecium bursaria; Str.vir, Strombidium viride; Vor.cam, Vorticella campanula

longirostris was affected by phytoplankton. Biomass of larval- and juvenile-stage $E$. graciloides increased along with increases in bacterial biomass. The length of the variability gradient and position on the graph of D. galeata $\times$ longispina and E. graciloides suggested that they contributed significantly to the total biomass of species incorporated in the analysis, but their biomasses were affected by all the food sources (Fig. 2B).

\section{Discussion}

Allochthonous subsidies versus phytoplankton

It is generally accepted that nutrient additions can directly affect primary productivity and can lead to bottom-up control of trophic dynamics, and thus might have an indirect effect on the length of food chains and growth rates of populations (DeAngelis, 1980). We found that inputs of allochthonous nutrients resulted in increases of phytoplankton biomass. Our analysis pointed out allochthonous nutrients, $\mathrm{N}-\mathrm{NO}_{3}, \mathrm{~N}-\mathrm{NH}_{4}$, and $\mathrm{P}-\mathrm{PO}_{4}$, as important driving forces for phytoplankton biomass, as they explained more than a half of variance in phytoplankton biomass. Availability of allochthonous nutrients was related to temperature and $\mathrm{pH}$. These variables also influenced the grazing pressure of omnivores on phytoplankton. In general, temperature affects all levels of the aquatic food webs due to its impact on all vital functions of the organisms in the food web. This is due to the fact that temperature directly plays a role in reducing or enhancing metabolism and reproduction rates (Frey, 1982; Gillooly \& Dodson, 2000; deEyto \& Irvine, 2001; Bozkurt et al., 2016), and thus, it has multiple indirect effects on the habitats of the aquatic communities altering food resources. We found that higher temperature conduced to assimilation of nutrients as well as eager grazing of phytoplankton by omnivores. Decrease in temperature coincided with the shift in grazing preferences of omnivores toward allochthonous organic matter. The role of $\mathrm{pH}$ in aquatic ecosystems is often considered in the view of considerable acidification and alkalinization (Shindler et al., 1985; Labaj et al., 2014; Zhang et al., 2014). pH of the studied lake ranged between 6.2 and 8.4. This variation of $\mathrm{pH}$ might be an effect of photosynthetic production which employs bicarbonates as a source of $\mathrm{CO}_{2}$ and thus contributes to photosynthetically mediated $\mathrm{CaCO}_{3}$ precipitation (Galbraith \& Burns, 2007; Pomar \& Hallock, 2008). Although $\mathrm{pH}$ of a lake depends on phytoplankton abundance in water, it is not always the case. In terms of shallow polymictic Łęczna-Włodawa lake, Ferencz \& Dawidek (2018) found that $\mathrm{pH}$ is determined by hydrological conditions and confluence of the lake, whereas chl-a is shaped by complex limnetic conditions. Ferencz \& Dawidek (2015) associated summer alkaline conditions in the water of Lake Syczyńskie with high rate of groundwater recharge from Cretaceous aquifer. Elevated $\mathrm{pH}$ that temporarily occurred in the studied lake had a negative influence on the assimilation of all forms of nutrients and diminished the grazing pressure of omnivores on phytoplankton. $\mathrm{pH}$ generally correlates positively with bacteria and HNF (Yannarell \& 
Triplett, 2004; Lindström et al., 2005; Gaedke \& Kamjunke, 2006); thus, the diminished grazing pressure of omnivores on phytoplankton under elevated $\mathrm{pH}$ could be caused by enhanced metabolic activity of bacteria and HNF. Some studies report that dissolved organic matter mediated by bacteria and microheterotrophs is important for the nutrition of zooplankton in both humic and clear lakes (Salonen \& Hammar, 1986; Emery et al., 2015). Thus, in the periods of elevated $\mathrm{pH}$, microorganisms not only might be grazed by omnivores but also might improve the availability of organic matter. Earlier studies proved that allochthonous resources lead to poor growth and reproduction of planktonic animals (Kelly et al., 2014; Karlson et al., 2015), although they may obtain substantial amount of carbon through direct consumption of allochthonous organic particles (Carpenter et al., 2005; Cole et al., 2006). Due to agricultural characteristics of the lake catchment, a dominance of dissolved organic nitrogen was observed most frequently in Lake Syczyńskie (Ferencz et al., 2014). To sum up, the results confirmed our hypothesis that allochthonous subsidies have a positive impact on phytoplankton biomass by providing available nutrients and diminishing the grazing pressure of omnivores.

\section{Allochthonous subsidies versus bacteria and HNF}

We found that assimilability of organic matter by bacteria was related to $\mathrm{pH}$ and temperature. However, there were no significant relationships between allochthonous subsidies and biomass of bacteria. The influence of organic matter, especially dissolved forms, on the biomass of bacteria differs in lakes in relation to their trophy; in eutrophic lakes, organic matter has a weak stimulatory effect on the production of bacteria (Stets \& Cotner, 2008). However, we found that the more alkaline environment conduced bacteria to utilization of TOC. $\mathrm{pH}$ influences the biomass, ion transport system (Guffanti et al., 1984), and metabolic rate of bacteria (Mayo \& Noike, 1994). Additionally, as elevated $\mathrm{pH}$ had a negative influence on assimilation of all forms of nutrients in the studied lake, bacteria might utilize allochthonous TOC as a source of energy and elements necessary to build their biomass. Our analyses suggest competitive interactions between phytoplankton and bacteria. Some studies indicate that bacteria account for a large portion of total uptake of both phosphorus and nitrogen in water environments (Kirchman, 1994) resulting in nutrient limitation for phytoplankton assemblages (Joint et al., 2002). Obviously, perished phytoplanktonic cells may be a source of both carbon and nutrients for bacteria. However, we found negative relationships among bacteria and phytoplankton; thus, phytoplankton was not the source of available organic carbon and nutrients for bacteria in the studied lake. Biomass of bacteria showed a linear positive relationship with phytoplankton under the conditions of elevated EC. EC indicates the level of micro- and macroelements. So, when EC increased, i.e., more mineral elements were present in water, biomasses of both phytoplankton and bacteria increased too. Thus, phytoplankton and bacteria competed not only for nutrients but also for other essential elements. Similarly to bacteria, HNF displayed negative relationships with phytoplankton. Taking into consideration that $\mathrm{HNF}$ is a direct grazer of bacteria, negative correlations between phytoplankton and HNF may be explained as an indirect effect of competitive relationships between phytoplankton and bacteria, according to the following scenario: higher biomass of phytoplankton leads to lower biomass of bacteria which in turn leads to lower biomass of HNF due to lower amount of food. Allochthonous TSS were an important source of food for HNF. Size spectrum of particles consumed by HNF ranges from 0.2 to $>50 \mu \mathrm{m}$ (Arndt et al., 2000). TSS comprise particles of diameter between $1 \mathrm{~nm}$ and $1 \mu \mathrm{m}$. Considering that the size of bacterial cells ranges from 0.5 to $5 \mu \mathrm{m}$, the biomass of some smaller bacteria might be detected as TSS; however, they did not constitute an important part of TSS, as bacterial biomass did not display any relationship with TSS. HNF are generally considered as bacterivores (Nagata, 1988; Sintes \& del Giorgio, 2014). Our research suggests that HNF might also directly utilize allochthonous TSS; however, the above evidence on the relationships among phytoplankton, bacteria, and HNF suggests that allochthonous TSS did not compensate for scarcity of bacterial source of food. Therefore, our hypothesis was not fully supported, for we found that availability of allochthonous TOC had a weak impact on the biomass of bacteria, whereas utilization of allochthonous nutrients by bacteria was impeded by competitive influence of phytoplankton. Additionally, competitive interactions among bacteria and phytoplankton unsettled the 
direct predator-prey relationships between HNF and bacteria.

Allochthonous subsidies versus trophic structure of omnivores

We observed that food quantity did not have a significant effect on the biomass of omnivorous Ciliata. In our examination, only four omnivorous species showed their relation to autochthonous versus allochthonous food sources. Biomass of $P$. bursaria was affected by allochthonous TOC, biomass of Bursellopsis sp. and $S$. viride increased together with the biomass of bacteria, and biomass of $V$. campanula was affected by all the food sources. Of the factors studied, organic carbon and bacterial biomass had the strongest impact on the growth of ciliates population. The overwhelming importance of food resource and organic matter has been confirmed with several freshwater species of peritrichids and oligotrichs (Weisse et al., 2002). Food significantly influenced the biomass of Crustacea. Among Cladocera, feeding preferences of B. longirostris shifted toward phytoplankton, whereas $D$. galeata $\times$ longispina showed equal preferences to all types of food. Feeding preferences of the cladocerans in the studied lakes were in accordance with experimental studies on the feeding selectivities of Daphnia and Bosmina (DeMott, 1986). Subsidies of allochthonous sources of food in Lake Syczyńskie may not be important for $B$. longirostris, for that species is able to feed efficiently even at low food concentrations (DeMott, 1982). D. galeata $\times$ longispina occurred to be a feeding opportunist. Daphnia sp. may assimilate high amounts of phosphorus because of their high phosphorus content (Schulz \& Sterner, 1999); thus, autochthonous subsidies as the sole sources of food may not satisfy Daphnia's necessity for phosphorus. Among Copepoda, larval-stage E. graciloides showed feeding preferences toward bacteria. According to the literature, nauplii are able to assimilate a wide spectrum of food, including pico- and nanophytoplankton (Uye \& Kasahara, 1983), and bacterioplankton (Roff et al., 1995); however, they show higher rates of clearance of bacteria in the absence of appropriate phytoplankton food (Turner \& Tester, 1992). Supported by allochthonous nutrients, abundant sources of bacteria as food could affect the development of nauplii, of which the highest number endured to juvenile stages. We found that juvenile and adult $E$. graciloides displayed no clear feeding preferences suggesting their feeding opportunity. In general, most calanoids including E. graciloides prefer living cells over detritus (DeMott, 1986); however, they can also be facultative detritivores and select detrital particles based on their quality when average particle quality becomes low (Kerfoot \& Kirk, 1991). Our studies demonstrated that E. graciloides effectively utilized a variety of allochthonous and autochthonous sources of food. Above results suggested that quality of food (autochthonous versus allochthonous) did not have any influence on diversity and biomass of omnivorous Ciliata and Crustacea due to their ability of effective utilization of both allochthonous and autochthonous food. Thereby, our third hypothesis was not confirmed.

\section{Conclusions}

Our results lead to the conclusion that allochthonous inputs may be key components that explain variation in primary and secondary productions in autotrophic lakes. Allochthonous subsidies can directly affect the relationships among components of the lower trophic levels by weakening competitive interactions between bacteria and phytoplankton for nutrients, as well as may have an indirect effect on abundance of autotrophic plankton as a result of decreased predatory impact of planktonic omnivores on phytoplankton by loading surrogate food. Thus, allochthonous subsidies impact both heterotrophic and autotrophic energy mobilization through food chains by providing external matter and dissolved nutrients, as well as may autonomize higher trophic levels by providing organic particles eagerly eaten by omnivorous consumers.

Acknowledgements The research was supported by the Grant (No. NCN 2015/17/D/ST10/02105) of National Science Center (NCN), Poland. We thank the two anonymous reviewers for their constructive criticism which helped greatly improve the previous draft of the paper.

Open Access This article is distributed under the terms of the Creative Commons Attribution 4.0 International License (http:// creativecommons.org/licenses/by/4.0/), which permits unrestricted use, distribution, and reproduction in any medium, provided you give appropriate credit to the original author(s) and the source, provide a link to the Creative Commons license, and indicate if changes were made. 


\section{References}

Adamczuk, M., T. Mieczan, D. Nawrot \& J. Rechulicz, 2015. Indirect effects of environmental factors on interactions between microbial and classical food webs in freshwater ecosystems. Annales de Limnologie 51: 49-58.

Arndt, H., D. Dietrich, B. Auer, E.-J. Cleven, T. Gräfenhan, M. Weitere \& A. P. Mylnikov, 2000. Functional diversity of heterotrophic flagellates in aquatic ecosystems. In Leadbeater, B. S. C. \& J. C. Green (eds), The Flagellates: Unity, Diversity and Evolution. Taylor \& Francis, London: 240-268.

Belle, S., V. Verneaux, A. L. Mariet \& L. Millet, 2017. Impact of eutrophication on the carbon stable-isotopic baseline of benthic invertebrates in two deep soft-water lakes. Freshwater Biology 62: 1105-1115.

Bottrell, H. H., A. Duncan, Z. M. Gliwicz, E. Grygierek, A. Herzig, A. Hillbricht-Ilkowska, H. Kurasawa, P. Larsson \& T. Węgleńska, 1976. Review of some problems in zooplankton production studies. Norwegian Journal of Zoology 24: 419-456.

Bozkurt, A., M. Ülgü \& Ö. Duysak, 2016. The determination of body size and eggs number of zooplankton (Rotifera, Cladocera and Copepoda) in Tahtaköprü Dam Lake (Gaziantep, Turkey). LIMNOFISH-Journal of Limnology and Freshwater Fisheries Research 2: 1-9.

Brett, M. T., M. J. Kainz, S. J. Taipale \& H. Seshan, 2009. Phytoplankton, not allochtonous carbon, sustains herbivorous zooplankton production. Proceedings of the National Academy of Sciences of the United States of America 106: 21197-21201.

Carpenter, S., J. Cole, M. L. Pace, M. Van de Bogert, D. Bade, D. Bastviken, C. M. Gille, J. R. Hogson, J. F. Kitchell \& E. S. Kritzberg, 2005. Ecosystem subsidies: terrestrial support of aquatic food webs from ${ }^{13} \mathrm{C}$ addition to contrasting lakes. Ecology 86: 2737-2750.

Cole, J. J., S. R. Carpenter, M. L. Pace, M. C. Van de Bogert, J. L. Kitchell \& J. R. Hodgson, 2006. Differential support of lake food webs by three types of terrestrial organic carbon. Ecology Letters 9: 558-568.

Corman, J. R., B. L. Bertolet, N. J. Casson, S. D. Sebestyen, R. K. Kolka \& E. H. Stanley, 2018. Nitrogen and phosphorus loads to temperate seepage lakes associated with allochthonous dissolved organic carbon loads. Research Letters. https://doi.org/10.1029/2018GL077219.

Culver, D. A., M. M. Boucherle, D. J. Bean \& W. J. Fletcher, 1985. Biomass of freshwater crustacean zooplankton from lenght-weight regression. Canadian Journal of Fisheries and Aquatic Sciences 42: 1380-1390.

DeAngelis, D. L., 1980. Energy flow, nutrient cycling, and ecosystem resilience. Ecology 61: 764-771.

deEyto, E. \& K. Irvine, 2001. The response of three chydorid species to temperature, $\mathrm{pH}$ and food. Hydrobiologia 459: $165-172$.

DeMott, W. R., 1982. Feeding selectivities and relative ingestion rates of Daphnia and Bosmina. Limnology and Oceanography 27: 518-527.

DeMott, W. R., 1986. The role of taste in food selection by freshwater zooplankton. Oecologia 69: 334-340.
Dumont, H. J., I. Van de Velde \& S. Dumont, 1975. The dry weight estimate of biomass in selection of Cladocera, Copepoda and Rotifera from the plankton, periphiton and benthos of continental waters. Oecologia 19: 75-97.

Elser, J. J., M. E. S. Bracken, E. E. Cleland, D. S. Gruner, W. S. Harpole, H. Hillebrand, J. T. Ngai, E. W. Seabloom, J. B. Shurin \& J. B. Smith, 2007. Global analysis of nitrogen and phosphorus limitation of primary producers in freshwater, marine and terrestrial ecosystems. Ecology Letters 10: $1135-1142$.

Emery, K. A., G. M. Wilkinson, F. G. Ballard \& M. L. Pace, 2015. Use of allochtchonous resources by zooplankton in reservoirs. Hydrobiologia 758: 257-269.

Ferencz, B. \& J. Dawidek, 2015. The variability of conditions of carbonate allocation on the example of a small flowthrough łęczna-Włodawa lake (eastern Poland). Environmental Earth Sciences 73: 1601-1610.

Ferencz, B. \& J. Dawidek, 2018. The role of confluence in shaping water quality parameters on example of the flowthrough Lake Bikcze (eastern Poland). Water 10: 679.

Ferencz, B., J. Dawidek \& M. Toporowska, 2014. Hydrochemical versus biological conditions of the functioning of three shallow lakes in Łęczna-Włodawa. Water Environment Research 86: 269-276.

Ferencz, B., J. Dawidek \& M. Toporowska, 2018. Instability of water quality of a shallow, polymictic, flow-through lake. Water Air Soil Pollution 229: 141.

Finlay, B. J., 1982. Procedures for the isolation, cultivation and identification of protozoa. Experimental Microbiology and Ecology 1: 44-65.

Frey, D. G., 1982. Contrasting strategies of gametogenesis in northern and southern populations of Cladocera. Ecology 63: 223-241.

Gaedke, U. \& N. Kamjunke, 2006. Structural and functional properties of low-and high-diversity planktonic food webs. Journal of Plankton Research 28: 707-718.

Galbraith, L. M. \& C. W. Burns, 2007. Linking land-use, water body type and water quality in southern New Zealand. Landscape Ecology 22: 231-241.

Gilbert, D., C. Amblard, G. Bourdier \& A. J. Francez, 1998. The microbial loop at the surface of a peatland: structure, functioning and impact of nutrients inputs. Microbial Ecology 35: 89-93.

Gillooly, J. F. \& S. I. Dodson, 2000. Latitudinal patterns in the size distribution and seasonal dynamics of new world, freshwater cladocerans. Limnology and Oceanography 45: 22-30.

Grizzetti, B., P. Passy, G. Billen, F. Bouraoui, J. Garnier \& L. Lassaletta, 2015. The role of water nitrogen retention in integrated nutrient management: assessment in a large basin using different modelling approaches. Environmental Research Letters 10: 065008.

Guffanti, A. A., M. Mann, T. L. Sherman \& T. A. Krulwich, 1984. Patterns of electrochemical proton gradient formation by membrane vesicles from an obligatory acidophilic bacterium. Journal of Bacteriology 159: 448-452.

Huont, Y., M. Babin, F. Bruyant, C. Grob, M. S. Twardowski \& H. Claustre, 2007. Does chlorophyll a provide the best index of phytoplankton biomass for primary productivity studies? Biogeosciences Discussions, European Geoscience Union 4: 707-745. 
Jerome, C. A., D. J. S. Montagnes \& F. J. R. Taylor, 1993. The effect of the quantitative protargol stain and Lugols and Buinos fixatives on cell size: a more accurate estimate ciliate species biomass. Journal of Eukaryotic Microbiology 40: 254-259.

Joint, I., P. Henriksen, G. A. Fonnes, D. Bourne, T. F. Thingstad, T. Frede \& B. Riemann, 2002. Competition for inorganic nutrients between phytoplankton and bacterioplankton in nutrient manipulated mesocosms. Aquatic Microbial Ecology 29: 145-159.

Jones, J. R. \& M. F. Knowlton, 2005. Chlorophyll response to nutrients and non-algal seston in Missouri Reservoirs and oxbow lakes. Lake and Reservoir Management 21: 361-371.

Karlson, J., A.-K. Bergström, P. Byström, C. Gudasz, P. Rodríguez \& C. Hein, 2015. Terrestrial organic matter input suppresses biomas production in lake ecosystems. Ecology 96: 2870-2876.

Kelly, P. T., T. C. Solomon, B. C. Weidel \& S. E. Jones, 2014. Terrestrial carbon is a resource, but not a subsidy, for lake zooplankton. Ecology 95: 1236-1242.

Kerfoot, W. C. \& K. L. Kirk, 1991. Degree of taste discriminating among suspension-feeding cladocerans and copepod: implications for detrivory and herbivory. Limnology and Oceanography 36: 1107-1123.

Kirchman, D. L., 1994. The uptake of inorganic nutrients by heterotrophic bacteria. Microbial Ecology 28: 255-271.

Labaj, A. L., A. Jeziorski, J. Kurek \& J. P. Smol, 2014. Longterm trends in Cladocera assemblages related to acidification and subsequent liming of Middle Lake (Sudbury, Canada). Water, Air and Soil Pollution 225: 1868.

Lindström, E. S., M. P. Kamst-Van Agterveld \& G. Zwart, 2005. Distribution of typical freshwater bacterial groups is associated with $\mathrm{pH}$, temperature, and lake water retention time. Applied and Environmental Microbiology 71: 8201-8206.

Malmaeus, J. M. \& L. Håkanson, 2003. A dynamic model to predict suspended particulate matter in lakes. Ecological Modelling 167: 247-262.

Mayo, A. W. \& T. Noike, 1994. Response of mixed culture of Chlorella vulgaris and heterotrophic bacteria to variation of $\mathrm{pH}$. Water Science and Technology 30: 285-294.

Mieczan, T., 2010. Ciliates in three shallow lakes in eastern Poland: a comparative study between a phytoplanktondominated lake, a phytoplankton-macrophyte lake and a macrophyte-dominated lake. Zoological Studies 49: 589-600.

Moorhouse, H. L., S. McGowan, Z. E. Taranu, I. GregoryEaves, P. R. Leavitt, M. D. Jones, P. Barker \& S. A. Brayshaw, 2018. Regional versus local drivers of water quality in the Windermere catchment, Lake District, United Kingdom: the dominant influence of wastewater pollution over the past 200 years. Global Change Biology 24: 4009-4022.

Nagata, T., 1988. The microflagellate-picoplankton food linkage in the water column of Lake Biwa. Limnology and Oceanography 33: 504-517.

Nõges, T., 2009. Relationships between morphometry, geographic location and weather quality parameters of European lakes. Hydrobiologia 633: 33-43.
Oksanen, L., S. D. Fretwell, J. Arruda \& P. Niemela, 1981. Exploitation ecosystems in gradient of primary productivity. The American Naturalist 118: 240-261.

Piña-Ochoa, E. \& M. Álvarez-Cobelas, 2006. Denitrification in aquatic environments: a cross-system analysis. Biogeochemistry 8: 111-130.

PN-EN ISO 6878, 2006. Water Quality. Determination of Phosphorus - Spectrophotometric Method with Ammonium Molybdate. PKN, Warsaw. (In Polish).

PN-ISO 7150, 2002, 2002a. Water Quality. Determination of Ammonium Nitrogen. PKN, Warsaw. (In Polish).

PN-ISO 7150, 2002, 2002b. Water Quality. Measurement of Biochemical Parameters. Spectrophotometrical Determination of Chlorophyll-a Concentration. PKN, Warsaw. (In Polish).

Pomar, L. \& P. Hallock, 2008. Carbonate factories: a conundrum in sedimentary geology. Earth-Science Reviews 87: 134-169.

Porter, K. G. \& Y. S. Feig, 1980. The use of DAPI for identifying and counting aquatic microflora. Limnology and Oceanography 25: 943-948.

Powers, S. M., J. L. Tank \& D. M. Robertson, 2015. Control of nitrogen and phosphorus transport by reservoirs in agricultural landscapes. Biogeochemistry 124: 417-439.

Riemann, B., G. F. Steward \& F. Azam, 2000. Dynamics of bacterial community composition and activity in mesocosm diatom bloom. Applied and Environmental Microbiology 66: 578-587.

Roff, J. C., J. T. Turner, M. K. Webber \& R. R. Hopcroft, 1995. Bacterivory by tropical copepod nauplii: extent and possible significance. Aquatic Microbial Ecology 9: 165-175.

Rosenzweig, M. L., 1971. Paradox of enrichment: destabilization of exploitation ecosystems in ecological time. Science 171: 385-387.

Roughgarden, J., 1975. A simple model for population dynamics in stochastic environments. The American Naturalist 109: 713-736.

Salonen, K. \& K. T. Hammar, 1986. On the importance of dissolved organic matter in the nutrition of zooplankton in some lake waters. Oecologia 68: 246-253.

Schulz, K. L. \& R. W. Sterner, 1999. Phytoplankton phosphorus limitation and food quality for Bosmina. Limnology and Oceanography 44: 1549-1556.

Shindler, D. W., M. A. Turner \& R. H. Hesslein, 1985. Acidification and alkalization of lakes by experimental addition of nitrogen compounds. Biogeochemistry 1: 117-133.

Simon, M., 1987. Biomass and production of small and large freeliving and attached bacteria in Lake Constance. Limnology and Oceanography 32: 591-607.

Sintes, E. \& P. A. del Giorgio, 2014. Feedbacks between protistan single-cell activity and bacterial physiological structure reinforce the predator/prey link in microbial foodwebs. Frontiers in microbiology 5: 1-11.

Smal, H., R. Kornijów \& S. Ligęza, 2005. The effect of cathment on water quality and eutrophication risk of five shallows lakes (Polesie Region, Eastern Poland). Polish Journal of Ecology 53(3): 313-327.

Søndergaard, M., P. D. Jensen \& E. Jeppesen, 1999. Internal phosphorus loading in shallow Danish lakes. Hydrobiologia 408(409): 145-152. 
Stets, E. G. \& J. B. Cotner, 2008. The influence of dissolved organic carbon on bacterial phosphorus uptake and bacteria-phytoplankton dynamics in two Minessota lakes. Limnology and Oceanography 53: 137-147.

Taipale, S. J., T. M. Brett, M. W. Hahn, D. Martin-Creuzburg, S. Yeung, M. Hiltunen, U. Stranberg \& P. Kankaala, 2014. Differing Daphnia magna assimilation efficiencies for terrestrial, bacterial and algal carbon and fatty acids. Ecology 95: 563-576.

terBraak, C. J. F. \& P. Smilauer, 2002. Canoco reference manual and CanoDraw for Windows user's guide: software for canonical community ordination (Version 4.5). Microcomputer Power, Ithaca, New York, USA.

Toporowska, M. \& B. Pawlik-Skowrońska, 2014. Four-year study on phytoplankton biodiversity in a small hypertrophic lake affected by water blooms of toxigenic cyanobacteria. Polish Journal of Environmental Studies 23: 491-499.

Toporowska, M., B. Pawlik-Skowrońska \& R. Kalinowska, 2016. Mass development of diazotrophic cyanobacteria (Nostocales) and production of neurotoxic anatoxin-a in a Planktothrix (Oscillatories) dominated temperate lake. Water Air Soil Pollution 227: 321.

Turner, J. T. \& P. A. Tester, 1992. Zooplankton feeding ecology: bacterivory by metazoan microzooplankton. Journal of Experimantal Marine Biology and Ecology 160: 149-167.

Utermöhl, H., 1958. Zurvervollkommnung der quantitativen phytoplankton methodik. Internationale Vereinigung für Theoretische und Angewandte Limnologie: Mitteilungen 9: 1-38.

Uye, S. I. \& S. Kasahara, 1983. Grazing of various developmental stages of Pseudodiaptomus marinus(Copepoda:
Calanoida) on naturally occurring particles. Bulletin of Plankton Society of Japan 30: 147-158.

Vinebrooke, R. D. \& P. R. Leavitt, 1998. Direct and indirect effects of allochtonous dissolved organic matter, inorganic nutrients, and ultraviolet radiation on an alpine littoral food web. Limnology and Oceanography 43: 1065-1081.

Wan, Y., Y. Quian, K. W. Migliaccio, Y. Li \& C. Conrad, 2014. Linking spatial variations in water quality with water and land management using multivariate techniques. Journal of Environmental Quality 43: 599-610.

Weisse, T., P. Stadler \& E. S. Lindstrőm, 2002. Interactive effect of temperature and food concentration on growth rate: a test case using the small freshwater ciliate Urotricha farcta. Limnology and Oceanography 47: 1447-1455.

Yannarell, A. C. \& E. W. Triplett, 2004. Within- and betweenlake variability in the composition of bacterioplankton communities: investigations using multiple spatial scales. Applied and Environmental Microbiology 70: 214-223.

Zhang, L., S. Wang \& W. Zhihao, 2014. Coupling effects of $\mathrm{pH}$ and dissolved oxygen in water column on nitrogen release at water-sediment interface of Erhai Lake, China. Estuarine, Coastal and Shelf Science 149: 178-186.

Zwart, J. A., N. Craig, P. T. Kelly, S. D. Sebestyen, C. T. Solomon, B. V. Weidel \& S. E. Jones, 2015. Metabolic and physiochemical responses to a whole-lake experimental increase in dissolved organic carbon in a northtemperate lake. Limnology and Oceanography 61: $723-734$.

Publisher's Note Springer Nature remains neutral with regard to jurisdictional claims in published maps and institutional affiliations. 